\title{
Wartości preferowane przez młodzież studiującą i uczącą się a jej poczucie jakości życia
}

\section{Wprowadzenie}

Samo pojęcie wartość jest trudne do zdefiniowania. Jego istotę rozumie się inaczej w ekonomii, filozofii, socjologii, prawie, teologii, psychologii czy pedagogice. Można zatem uznać, że termin ten nie powinien być używany bez dodatkowych objaśnień. Do tej kwestii odniósł się m.in. na podstawie badań własnych M. Misztala, który na tej podstawie zaproponował trzy rodzaje definiowania wartości. Jego zdaniem, wartości są zjawiskiem o charakterze:

- psychologicznym, w którym wartość jest elementem systemu przekonań jednostki o charakterze normatywnym;

- socjologicznym; wartość oznacza tu przekonania jednostek lub grup społecznych, określające godne pożądania cechy poszczególnych grup społecznych lub społeczeństwa jako całości;

- kulturowym - wartość to przekonanie na temat norm uważanych za godne pożądania dla danego społeczeństwa ${ }^{1}$.

Ze względu na przedstawione w artykule wyniki badań własnych odnoszące się do preferowanych wartości przez młodzież studiującą i uczącą się przytoczono wybrane definicje wartości odwołujące się do ich kontekstu rozwojowego. Taki kontekst tego pojęcia oddaje np.

M. Misztal, Problematyka wartości w socjologii, PWN, Warszawa 1980, s. 20-33. 
definicja K. Dąbrowskiego. Autor ten charakteryzuje wartości jako „pewne specyficzne ludzkie właściwości ujmowane jako cele rozwojowe, jako to, co «być powinno», które wywodzą się (...) z wewnętrznych właściwości i zdolności podmiotu a (...) zgrupowane są w dwa rodzaje: wartości indywidualne i wspólne”. Jego zdaniem „wspólnymi dla wszystkich ludzi wartościami stają się empatia, autonomia, autentyzm, odpowiedzialność, wysoki poziom świadomości społecznej, a (...) indywidualne wartości wyrażają się przez zainteresowania, uzdolnienia i talenty"2.

$\mathrm{Na}$ konteksty rozwojowe zwraca też uwagę w swojej definicji wartości K. Popielski. Autor ten biorąc pod uwagę wymiar bytu ludzkiego, wyodrębnił:

wartości związane z wymiarem biologicznym (np. ogólne usprawnianie organizmu, sport, ćwiczenia relaksacyjne, nabywanie pozytywnych nawyków itd.); wartości związane $\mathrm{z}$ wymiarem psychicznym (np. rozwijanie sprawności intelektualnych, zdrowa atmosfera emocjonalna itd.); wartości związane z wymiarem noetycznym (np. spotkanie osobowe, przeżywanie wartości i sensu, świadomość wolności osobowej i odpowiedzialności, dążenie do celów i zadań, itd.) ${ }^{3}$.

Zdaniem M. Dziewieckiego, w praktyce wychowawczej wartości zajmują bardzo ważne miejsce. Nie można tak naprawdę wychowywać bez wartości. Stąd też od możliwie najwcześniejszych lat życia dziecka jego wychowanie powinno być skoncentrowane na takich zasadach postępowania, na których opiera się całe życie społeczne i osobiste człowieka. Dziecku niezbędne są jasne wzory, według których będzie w przyszłości postępowało. „W związku z tym oczywista jest potrzeba wychowania ku wartościom, czyli potrzeba udzielania takiej pomocy wychowawczej dzieciom i młodzieży, by mogły odkryć i respektować wartości"4.

Wartości odgrywają ogromną rolę w wychowaniu moralnym każdego człowieka. Wychowanie, które nie wprowadza dzieci i młodzieży w świat wartości, jest wychowaniem połowicznym, nieskutecznym

$2 \quad$ P. Oleś, Wartościowanie a osobowość. Psychologiczne badania empiryczne, Redakcja Wydawnictw KUL, Lublin 1989, s. 44.

3 K. Popielski, Sens i wartość życia jako kategorie antropologiczno-psychologiczne, [w:] K. Popielski (red.), Człowiek - pytanie otwarte, Redakcja Wydawnictw KUL, Lublin 1987, s. 107-139.

4 M. Dziewiecki, Wychowanie ku wartościom (1), „Wychowawca” 1998, nr 9, s. 4-5. 
i wręcz społecznie szkodliwym. Taka sytuacja pozbawia wychowanków możliwości odróżniania dobra od zła, a tym samym podejmowania decyzji ważnych życiowo i zgodnych z uniwersalnymi zasadami moralnymi ${ }^{5}$.

Ze względu na zastosowany w ramach badań własnych Portretowy Kwestionariusz (PVQ) Shaloma Schwartza warto odnieść się do podstaw teoretycznych tego narzędzia badawczego ${ }^{6}$. Koncepcja wartości Schwartza należy do coraz częściej wykorzystywanych przez współczesnych przedstawicieli nauk społecznych. Schwarz przedstawił po raz pierwszy jej założenia w latach osiemdziesiątych XX wieku? Od tej pory była ona kilka razy modyfikowana, chociaż główne jej zręby zostały zachowane. Badania weryfikujące jej teoretyczne założenia prowadzone były na wszystkich kontynentach, uczestniczyło w nich setki tysięcy osób.

Definiowanie przez Schwarza wartości jako przekonań sytuuje się tym samym podobnie jak u M. Rokeacha ${ }^{8} \mathrm{w}$ tradycji poznawczej. Tak rozumiane wartości-przekonania dotyczą pożądanych celów, stawianych sobie przez ludzi. Są to przy tym cele wykraczające poza konkretne działania i sytuacje. Do tego są one nasycone emocjami, a więc motywują jednostkę do działania i są również podstawą oceny własnych i cudzych zachowań. Taki sposób definiowania wartości przez Schwartza jest bliski dotychczasowej literaturze i tradycji badań prowadzonych w tym zakresie?.

Novum jego koncepcji jest zaproponowana struktura ludzkich wartości w kształcie uniwersalnego, motywacyjnego, kołowego kontinuum oraz ich katalog. Ważniejsze jest jednak dla Schwartza w jego koncepcji wartości pojęcie struktury niż jakakolwiek kategoryzacja wartości w ich katalogu ${ }^{10}$.

\footnotetext{
J. Reykowski, Teoria motywacji a zarządzanie, PWN, Warszawa 1975.

6 J. Cieciuch, Z. Zaleski, Polska adaptacja Portretowego Kwestionariusza Wartości Shaloma Schwartza, „Czasopismo Psychologiczne” 2011, t. 17, nr 2, s. 251-262.

$7 \quad$ S.H. Schwartz, W. Bilsky, Toward a psychological structure of human values, „Journal of Personality and Social Psychology" 1987, t. 53, s. 550-562.

$8 \quad$ M. Rokeach, The nature of human values, The Free Press, New York 1973.

9 J. Cieciuch, Z. Zaleski, Polska adaptacja Portretowego Kwestionariusza Wartości Shaloma Schwartza, „Czasopismo Psychologiczne” 2011, t. 17, nr 2, s. 252.

10 Ibidem, s. 252.
} 
Jeżeli chodzi o katalog wartości stworzony przez Schwartza to stanowi on propozycję kompletnego opisu ludzkich wartości. Przy czym, argumenty świadczące o owej kompletności mają wyłącznie charakter empiryczny. Schwartz przekonuje, że należy analizować nie tyle poszczególne wartości, lecz ich typy. Na kolejnych etapach rozwoju teorii proponował różną liczbę owych typów - od 7 do $11^{11}$.

W modelu klasycznym Schwartz wyróżnił zatem następujące 10 wartości:

1. Kierowanie sobą (self-direction, SD) - niezależność w myśleniu i działaniu, twórczość, wolność.

2. Stymulacja (stimulation, ST) - zmienność, nowość, podniecenie.

3. Hedonizm (hedonism, HE) - przyjemność, zmysłowe zaspokojenie.

4. Osiągnięcia (achievement, AC) - osobisty sukces osiągnięty dzięki własnym kompetencjom, zgodnie ze społecznymi standardami, ambicja.

5. Władza (power, PO) - status i prestiż społeczny, dominacja nad innymi ludźmi, kontrola ludzi i zasobów.

6. Bezpieczeństwo (security, SE) - harmonia, porządek i stabilizacja w całym społeczeństwie i relacjach międzyludzkich, bezpieczeństwo własne, bezpieczeństwo rodziny, bezpieczeństwo narodowe.

7. Przystosowanie (conformity, CO) - ograniczanie własnych działań, dążeń, impulsów, które mogłyby krzywdzić lub denerwować innych ludzi, naruszać społeczne oczekiwania lub normy.

8. Tradycja (tradition, TR) - akceptacja i podtrzymywanie zwyczajów, idei i tradycji własnej kultury, religii lub rodziny; respekt w stosunku do tradycji, pokora.

9. Życzliwość (benevolence, BE) - dbanie o dobro bliskich osób, członków rodziny, grupy, przyjaciół.

10. Uniwersalizm (universalism, UN) - zrozumienie, szacunek i tolerancja w stosunku do wszystkich ludzi; dobro wszystkich ludzi i przyrody ${ }^{12}$.

11 S.H. Schwartz, Basic human values: theory measurement and applications, „Revue francaise de sociologie" 2006, t. 47(4), s. 929-968.

12 J. Cieciuch, Kształtowanie się systemu wartości od dzieciństwa do dorosłości, Wydawnictwo Liberi Libri, Warszawa 2013, s. 57. 
Wymienionych 10 wartości tworzą cztery grupy wartości:

1. Przekraczanie siebie (self-transcendance), składająca się z uniwersalizmu i życzliwości.

2. Umacnianie siebie (self-enhancement), składająca się z władzy i osiągnięć.

3. Otwartość na zmiany (openness to change), składająca się z kierowania sobą i stymulacji.

4. Zachowawczość (conservation), składająca się z przystosowania, tradycji i bezpieczeństwa.

Hedonizm jest graniczną wartością, wchodzącą w skład dwóch sąsiadujących grup wartości - umacniania siebie i otwartości na zmiany. Cztery grupy wartości konstytuują krańce dwóch wymiarów. Te wymiary to: przekraczanie siebie versus umacnianie siebie i otwartość na zmiany versus zachowawczośćcis.

Na podstawie badań przeprowadzonych w 2012 roku Schwartz zmodyfikował swoją teorię wartości. W efekcie w jego kołowym modelu wartości znalazło się ich 19. Z punktu widzenia zmodyfikowanej teorii można też dodatkowo wzbogacić opis wartości. Dlatego też można przyjąć dwa nowe, główne wymiary motywacyjne, tzn.: koncentracja na sobie versus koncentracja na innych oraz ochrona siebie versus wzrost (rysunek 1.).

Wartości przekraczania siebie są w tym ujęciu motywowane wzrostem i koncentracją na innych. Wartości otwartości są podobne do przekraczania siebie pod względem motywacji wzrostu, ale różnią się pod względem drugiego wymiaru, ponieważ są motywowane koncentracją na sobie. Są zatem w tym zakresie podobne do wartości umacniania siebie, które są motywowane właśnie koncentracją na sobie oraz ochroną siebie. Z kolei wartości zachowawczości są motywowane również ochroną siebie (w czym są podobne do wartości umacniania siebie) oraz koncentracją na innych (w czym są podobne do wartości przekraczania siebie). Tym samym w proponowanej tu interpretacji dotychczasowe wymiary stają się grupami wartości, mierzonymi za pomocą kwestionariusza. Nowe wymiary (wzrost versus ochrona siebie oraz koncentracja na innych versus koncentracja na sobie) nie są bezpośrednio mierzone, ale organizują układ wartości i relacje między nimi ${ }^{14}$.

13 Ibidem, s. 57-58.

14 Ibidem, s. 64. 
Rysunek 1. Główne wymiary motywacyjne i grupy wartości, możliwe do wyróżnienia na gruncie zmodyfikowanej teorii wartości Schwartza ${ }^{15}$

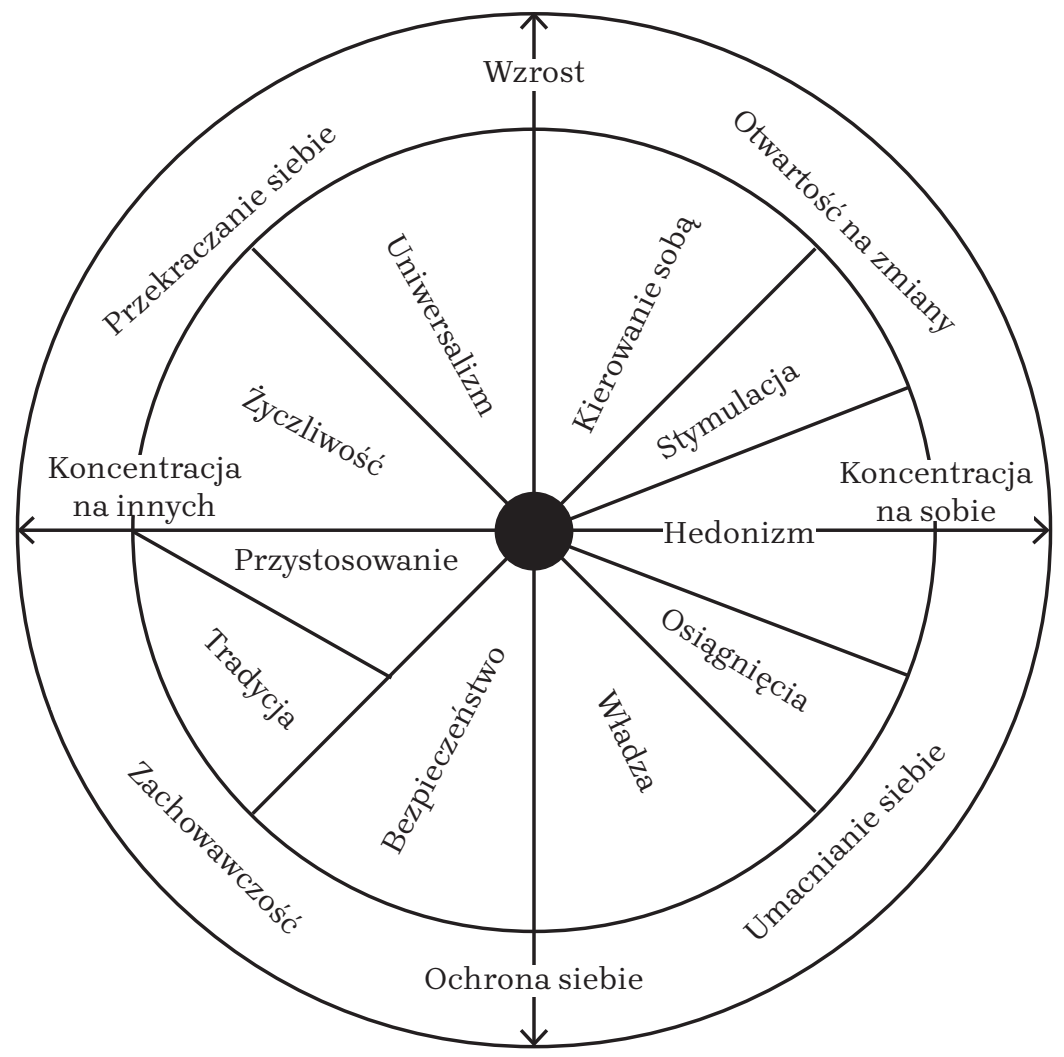

Źródło: opracowanie własne.

W związku z tym, że zmienną niezależną w ramach przeprowadzonych badań własnych jest poczucie jakości życia młodzieży uczącej się i studiującej krótkiej charakterystyki wymaga kwestia, wynikająca z faktu, że dobierając miary jakości życia i jego poczucia należy zauważyć, że w tym zakresie spotykamy w literaturze przedmiotu podejście obiektywne i subiektywne. Dlatego należy rozróżnić dwa terminy: ,jakość życia” i „poczucie jakości życia”. Przy tym mówiąc o „jakości życia” należy raczej zaakcentować sferę zewnętrzną, będącą źródłem

15 Ibidem. 
bodźców i doświadczeń osób. Jest ona przede wszystkim wynikiem obiektywnego pomiaru życia i „pojmowania” rzeczywistości ${ }^{16}$.

Jakość życia jest zarówno kategorią jednostkową jak również społeczną. Współczesne społeczeństwa coraz bardziej zainteresowane są polepszaniem jakości życia w sensie praktycznym - oczekują zaspokajania rosnących potrzeb materialnych, kulturalnych, atrakcyjnego wypoczynku, pracy i bezpieczeństwa. $\mathrm{Z}$ naukowego punktu widzenia oznacza to konieczność sprecyzowania pojęć i usystematyzowania terminologii dotyczącej omawianej problematyki. Jednocześnie nakazem chwili jest nowe spojrzenie na człowieka oraz jakość jego życia przez pryzmat wielowymiarowego rozwoju, co z perspektywy nauk społecznych stanowi szczególnie ważne zadanie ${ }^{17}$.

Jakość życia jest pojęciem względnym, które zależy nie tylko od zakresu objętych obserwacją i pomiarem obszarów ludzkiej egzystencji, lecz również od aspektów aksjologicznych i praktykowanych w życiu systemów wartości ${ }^{18}$. Każdy człowiek dąży w życiu do pewnych wartości, które kształtują jego decyzje i determinują postawy wobec otaczającej go rzeczywistości. Tym samym indywidualna ocena jakości życia powinna uwzględniać odpowiedzi na pytania: jakiej postaci życia własnego i życia innych ludzi pragniemy oraz do jakiego kształtu ludzkiego świata i własnego życia chcemy się przyczynić ${ }^{19}$. Wyznawane systemy wartości stanowią przesłankę do zróżnicowania percepcji jakości życia ludności przy względnie takich samych warunkach życia w ich obiektywnym ujęciu, a tym samym decydują o komplementarnym charakterze obiektywistycznych i subiektywistycznych koncepcji pomiaru tej kategorii ${ }^{20}$.

Poczucie jakości życia, jest najczęściej rozumiane w literaturze przedmiotu, jako subiektywne przekonanie na temat własnej oceny

16 J.W. Owsiński, T. Tarchalski, Pomiar jakości życia. Uwagi na marginesie pewnego rankingu, „Współczesne Problemy Zarządzania” 2008, nr 1, s. 8.

17 J. Daszykowska, Jakość życia w perspektywie pedagogicznej, Oficyna Wydawnicza „Impuls”, Kraków 2007, s. 17.

18 T. Borys, Jakość, jakość życia oraz pojęcia i relacje pochodne, [w:] W. Ostasiewicz, (red.), Ocena $i$ analiza jakości życia, Wydawnictwo Akademii Ekonomicznej we Wrocławiu, Wrocław 2004, s. 30.

19 A. Grzegorczyk, Życie jako wyzwanie, Wydawnictwo IFIS, Warszawa 1993, s. 96.

20 A. Campbell, Subjective Measures of Well-being, „American Psychologist” 1976, t. 31, nr 2, s. 117-124. 
życia. Posiada ono tak wymiar indywidualny jak i jednostkowy, przy tym angażujący więcej procesów psychicznych niż jakość życia ${ }^{21}$. Oceniając subiektywną jakość życia w jego poszczególnych wymiarach, człowiek charakteryzuje swój poziom zadowolenia. Podejmowanie prób realizacji wybranych przez daną osobę celów i kierunków dążeń, zależy w znacznym stopniu od akceptowanych przez nią wartości. To, jakie jednostka wyznaje wartości jest przy tym nie tylko kwestią jej wyboru, ale zależy również od wielu innych czynników. Zgodnie z holistycznym modelem M. Straś-Romanowskiej na poziom poczucia jakości życia składają się nie tylko zjawiska biologiczne i społeczne, ale także podmiotowe i duchowe ${ }^{22}$.

Dobre samopoczucie jest ważnym elementem zdrowia, a nierzadko nawet bywa z nim utożsamiane. Shin i Johnson definiują zadowolenie z życia jako „ogólną ocenę jakości życia odniesioną do wybranych przez siebie kryteriów"23. Na subiektywne dobre samopoczucie składają się trzy elementy:

1) poziom satysfakcji z życia;

2) pozytywne uczucia;

3) brak uczuć negatywnych ${ }^{24}$.

Ocena satysfakcji z życia jest wynikiem porównania własnej sytuacji z ustalonymi przez siebie standardami. Jeżeli wynik porównania jest zadowalający, to jego skutkiem jest odczucie satysfakcji.

Do pomiaru poczucia jakości życia młodzieży studiującej i uczącej się posłużyła Skala Satysfakcji z Życia autorstwa Dienera i współpracowników w polskiej adaptacji Juczyńskiego ${ }^{25}$. Składa się ona z pięciu twierdzeń, do których badany ustosunkowuje się oceniając, w jakim stopniu każde z nich odnosi się do jego dotychczasowego życia. Od-

21 R. Derbis, Doświadczanie codzienności: poczucie jakości życia, swoboda działania, odpowiedzialność, wartości osób bezrobotnych, Wydawnictwo WSiP, Częstochowa 2000; M. Straś-Romanowska, Jakość życia w świetle założeń psychologii zorientowanej na osobę, „Kolokwia Psychologiczne” 2005, nr 13, s. 262-274.

22 Ibidem.

23 D.C. Shin, D.M Johnson, Avowed Happiness as the Overall Assesment of the Quality of Life, „Social Indicators Research” 1978, t 5, s. 478.

24 W. Pavot, E. Diener, The affective and cognitive context of self-reported measures of subjective well-being, „Social Indicators Research” 1993, t. 28, s. 1-20.

25 Z. Juczyński, Narzędzia pomiaru w promocji i psychologii zdrowia. Skala Satysfakcji z Życia, Pracownia Testów Psychologicznych Polskiego Towarzystwa Psychologicznego, Warszawa 2001, s. 134-138. 
powiedzi udzielane są na siedmiostopniowej skali: od 1 - „zdecydowanie się nie zgadzam”, do 7 - „całkowicie się zgadzam”. Wynik ogólny stanowi suma wszystkich ocen. Zakres wyników mieści się w granicach od 5 do 35 punktów ${ }^{26}$. Im wyższe wyniki, tym większe poczucie satysfakcji z życia, które z kolei wykorzystano jako miarę poczucia jakości życia badanej młodzieży studiującej i uczącej się.

Przedstawione powyżej założenia teoretyczne wykorzystano jako podstawę doboru narzędzi badawczych oraz sformułowania celu badań własnych i problemów badawczych. Ich celem było ustalenie preferencji wartości w grupie badanej młodzieży uczącej się i studiującej i jej poczucia jakości życia oraz poziomu zależności między tymi zmiennymi.

W związku z tak określonym celem badań udzielono także w niniejszym artykule odpowiedzi na następujące pytania (problemy) badawcze:

1. Czy występuje zależność pomiędzy preferowanymi przez młodzież studiująca i ucząca wartościami a jej poczuciem jakości życia (główny problem badawczy)?

2. Jakie wartości preferuje młodzież studiująca i ucząca się (szczegółowy problem badawczy)?

3. Jaki jest poziom poczucia jakości życia młodzieży studiującej i uczącej się (szczegółowy problem badawczy)?

\section{Opis i interpretacja wyników badań}

\section{Próba badawcza - młodzież studiująca (grupa S) i ucząca się (grupa U)}

Badania przeprowadzono w pięciu uczelniach i pięciu szkołach średnich województwa lubelskiego. W badaniach uczestniczyło 100 studentów aktualnie studiujących na 4 lub 5 roku studiów II stopnia (magisterskich) oraz 100 uczniów ostatnich (maturalnych) klas szkół średnich. W grupie S znalazły się 74 kobiety i 26 mężczyzn, a w grupie U znalazły się 33 kobiety i 67 mężczyzn. Średnia wieku studentów (grupa S) - 24 lata, a uczniów (grupa U) - 19 lat. Zdecydowana większość badanych studentów i uczniów pochodzi ze wsi (grupa S - 42 osoby; grupa U - 67 osób. Pozostałe osoby to mieszkańcy miast (grupa S to

26 Ibidem. 
najczęściej miasta do 20 tys. mieszkańców - 24 osoby, a grupa U to najczęściej miasta od 20 tys. do 100 tys. mieszkańców - 23 osoby). Badane osoby to przede wszystkim studenci bezpieczeństwa narodowego (43 osoby) i pedagogiki (42 osoby). Pozostali respondenci z grupy S to studenci zarządzania (15 osób). Z kolei badane osoby z grupy W to uczniowie techników o kierunku mechanicznym (52 uczniów) i rolniczym (48 uczniów). Badania przeprowadzono w marcu i kwietniu 2019 roku. Miały one charakter grupowy. Wykorzystano w trakcie badań następujące narzędzia badawcze: Kwestionariusz Portraits Value Questionnaire (PVQ) S. Schwartza, którego adaptacji podstawowej 40-itemowej wersji dokonano dla polskiej populacji ${ }^{27}$ oraz Skala Satysfakcji z Życia (SWLS) autorstwa E. Dienera i współpracowników w polskiej adaptacji Z. Juczyńskiego ${ }^{28}$.

\section{Preferowane wartości przez młodzież studiującą i uczącą się}

Do najbardziej preferowanych wartości przez badanych studentów należały kolejno: uniwersalizm, kierowanie sobą i przystosowanie. Natomiast do najmniej preferowanych: władza, hedonizm i tradycja (rysunek 2). Wskaźniki preferencji ze znakiem plus lub minus, uzyskane w procedurze ipsatyzacji wyników oznaczają usytuowanie preferencji danej wartości w systemie wartości badanego. Przy czym średnia preferencja wynosi zero. Preferencje ze znakiem plus oznaczają preferencję wyższą niż średnia preferencja wartości danej osoby, natomiast wskaźniki ze znakiem minus - oznaczają preferencję poniżej średniej preferencji danej osoby. Warto też dodać, że w przypadku badanych studentów okazało się, że cenią oni sobie najbardziej kolejno następujące grupy wartości: przekraczanie siebie oraz zachowawczość. Z kolei w mniejszym stopniu preferują oni otwartość na zmiany, a w najmniejszym stopniu umacnianie siebie (rysunek 2).

27 J. Cieciuch, Z. Zaleski, Polska adaptacja Portretowego Kwestionariusza Wartości Shaloma Schwartza, „Czasopismo Psychologiczne” 2011, t. 17, nr 2, s. 251-262. 
Rysunek 2. Średnie ipsatywnych wskaźników preferencji wartości w grupie młodzieży studiującej (grupa S) umieszczone na kole wartości S. Schwartza Studenci $x_{\text {sr }}=2,98$

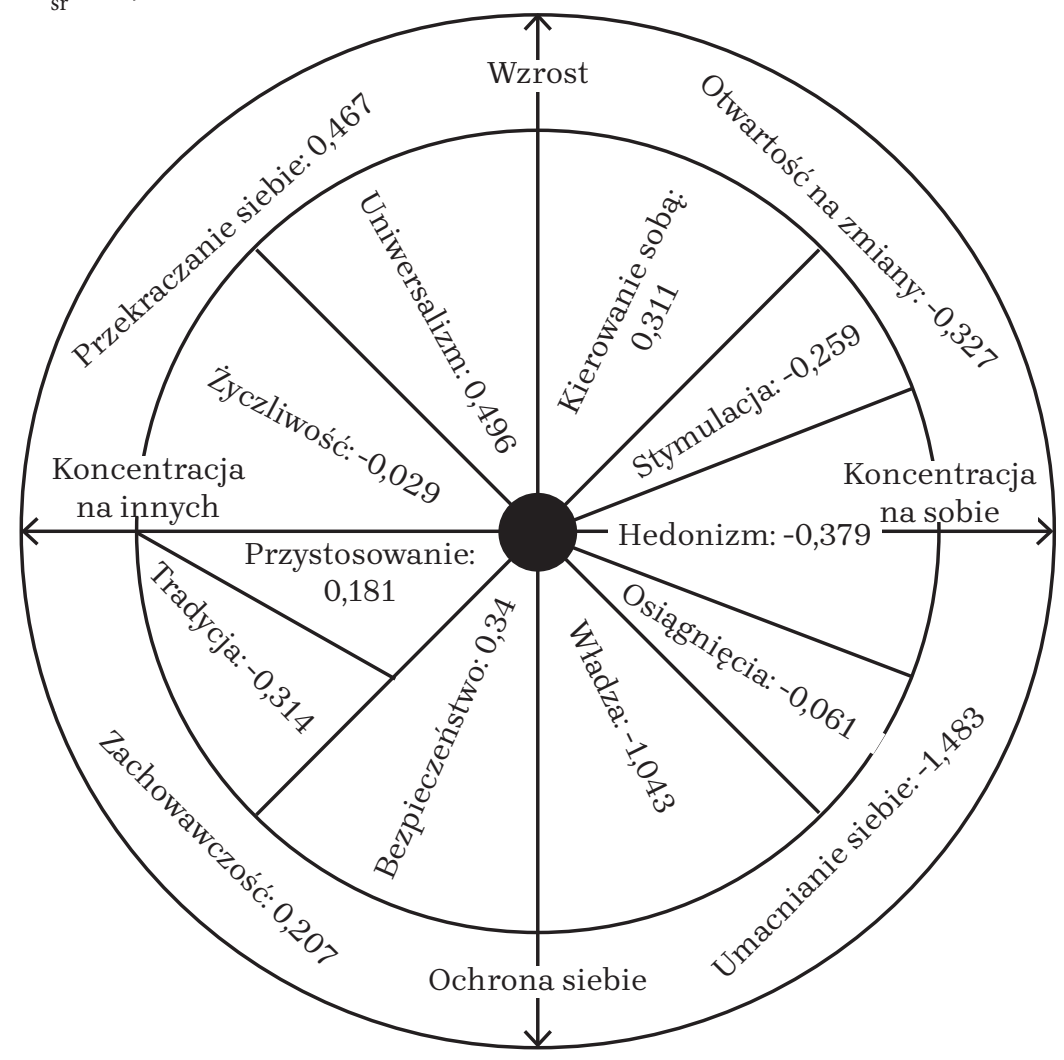

Źródło: opracowanie własne.

Badani uczniowie najbardziej preferowali kolejno takie wartości jak: życzliwość, kierowanie sobą i uniwersalizm. Natomiast najmniej preferowanymi przez nich wartościami były: władza i tradycja (rysunek 3). Warto też dodać, że w przypadku badanych uczniów okazało się, że cenią oni najbardziej następujące grupy wartości: przekraczanie siebie oraz otwartość na zmiany. Z kolei w mniejszym stopniu preferują oni zachowawczość, a w najmniejszym stopniu umacnianie siebie (rysunek 3). 
Rysunek 3. Średnie ipsatywnych ${ }^{29}$ wskaźników preferencji wartości w grupie młodzieży uczącej się (grupa U) umieszczone na modelu kole wartości S. Schwartza

Uczniowie $\mathrm{x}_{\text {sr }}=2,98$

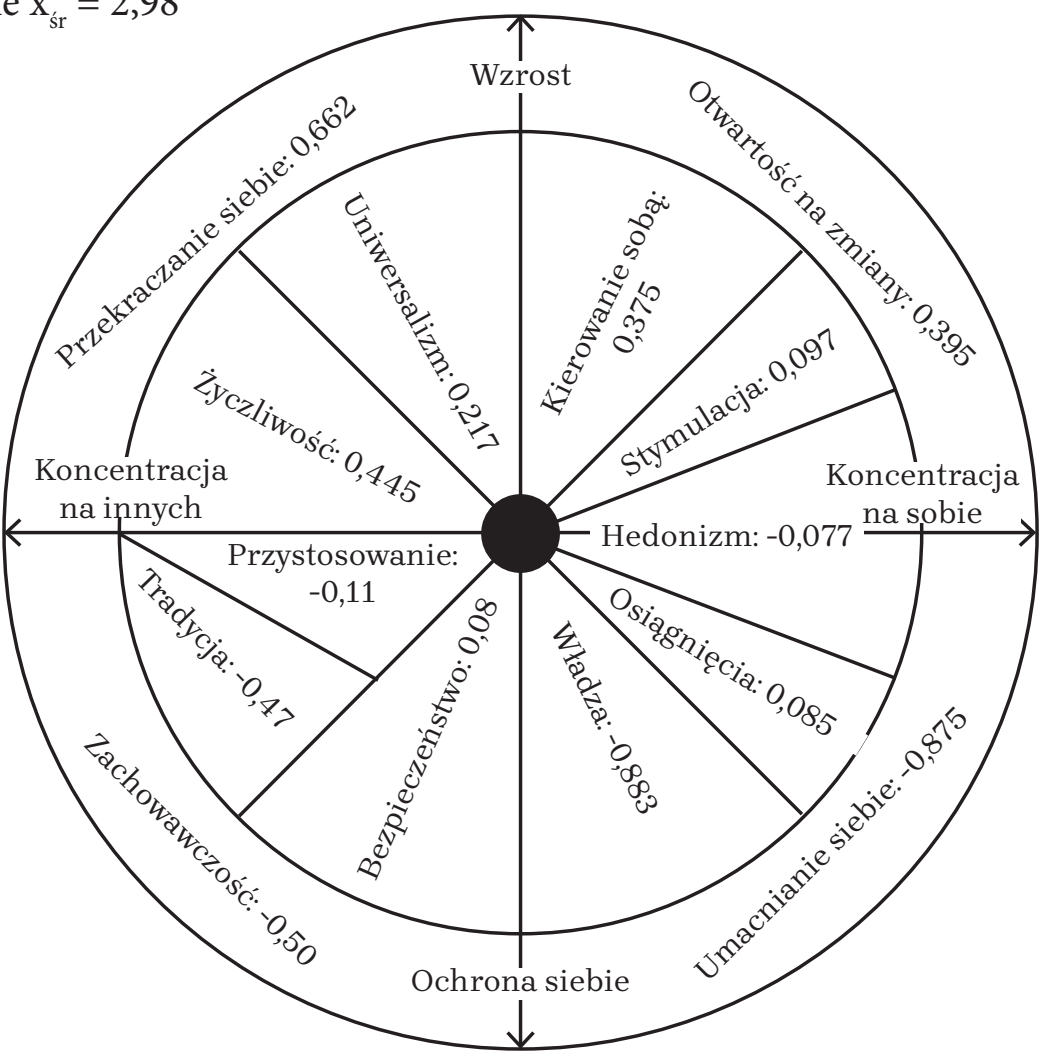

Źródło: opracowanie własne.

Powyższe opisy i interpretacje wyników badań własnych można też wzbogacić o nowe wymiary motywacyjne, które Schwartz uwzględnił w zmodyfikowanej przez siebie teorii wartości. W tej wersji swojej teorii uwzględnił on takie wymiary motywacyjne jak: koncentracja

29 Ipsatywny wskaźnik preferencji wartości to wskaźnik, który jest wynikiem różnicy pomiędzy średnią uzyskaną dla wszystkich wartości i średnią uzyskaną dla danego typu wartości. 
na sobie versus koncentracja na innych oraz ochrona siebie versus wzrost $^{30}$. Biorąc te wymiary pod uwagę można stwierdzić, że w przypadku badanej grupy studentów najwyższej preferowane wartości są w grupie nazwanej - przekraczanie siebie i są motywowane koncentracją na innych i wzrostem. Z kolei najmniej preferowane wartości znalazły się w grupie nazwanej - umacnianie siebie i są motywowane koncentracją na sobie i ochroną siebie (rysunek 3). Jeżeli chodzi o badanych uczniów to okazało się, podobnie jak u badanych studentów, że najbardziej preferowane przez nich wartości znalazły się w grupie nazwanej - przekraczanie siebie i są motywowane koncentracją na innych i wzrostem. W przypadku najmniej preferowanych wartości, również podobnie jak powyżej, znalazły się w grupie nazwanejumacnianie siebie i są motywowane koncentracją na sobie i ochroną siebie (rysunek 3).

Tabela 1. Różnice w preferencjach wartości między uczniami i studentami

\begin{tabular}{|l|c|c|c|c|c|}
\hline \multicolumn{1}{|c|}{ Wartości } & $\begin{array}{c}\text { Uczniowie } \\
\mathbf{n}=\mathbf{1 0 0}\end{array}$ & $\begin{array}{c}\text { Studenci } \\
\mathbf{n = 1 0 0}\end{array}$ & $\begin{array}{c}\text { Różnica } \\
\text { średnich }\end{array}$ & $\begin{array}{c}\text { test } \\
(\mathbf{d f}=\mathbf{1 9 8})\end{array}$ & $\mathbf{p}$ \\
\hline Życzliwość & $\mathbf{0 , 4 4 5}$ & $\mathbf{- 0 , 0 2 9}$ & $\mathbf{0 , 4 7 4 * *}$ & $\mathbf{2 , 4 2}$ & $\mathbf{0 , 0 2}$ \\
\hline Kierowanie sobą & 0,375 & 0,311 & 0,064 & 0,35 & ni. \\
\hline Uniwersalizm & 0,217 & 0,496 & $-0,279$ & 1,53 & ni. \\
\hline Stymulacja & 0,097 & $-0,259$ & 0,356 & 1,42 & ni. \\
\hline Osiągnięcia & 0,085 & $-0,061$ & 0,146 & 0,77 & ni. \\
\hline Bezpieczeństwo & 0,008 & 0,34 & 0,332 & 1,74 & ni. \\
\hline Hedonizm & $-0,077$ & $-0,379$ & 0,302 & 1,59 & ni. \\
\hline Przystosowanie & $-0,11$ & 0,181 & 0,071 & 0,89 & ni. \\
\hline Tradycja & $-0,47$ & $-0,314$ & 0,156 & 0,79 & ni. \\
\hline Władza & $-0,883$ & $-1,043$ & 0,147 & 0,80 & ni. \\
\hline
\end{tabular}

$\mathrm{p}<.05,{ }^{*} \mathrm{p}<.02,{ }^{* *} \mathrm{p}<.01,{ }^{* * * *} \mathrm{p}<.001$

Źródło: opracowanie własne.

$\overline{30}$ J. Cieciuch, Kształtowanie się systemu wartości..., s. 63-64. 


\section{Wykres 1. Różnice w preferencjach wartości między uczniami i studentami}

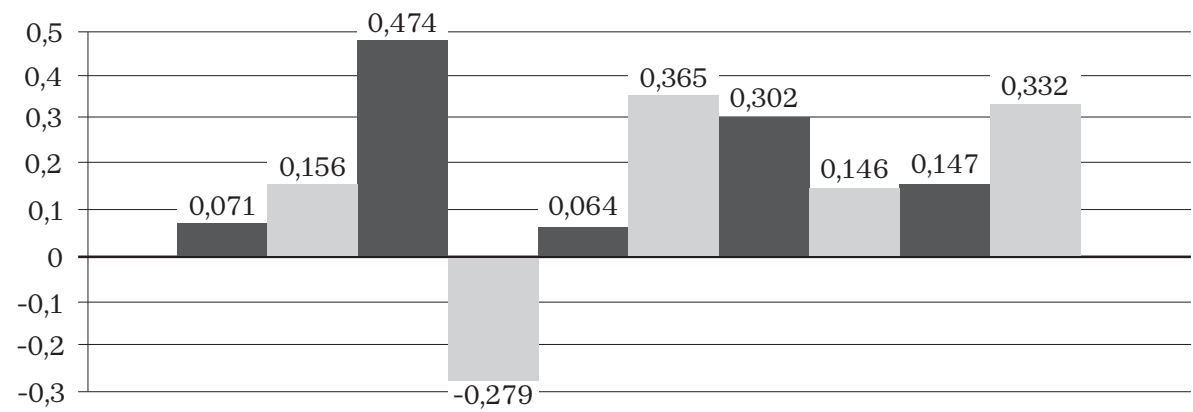

\begin{tabular}{|c|c|c|c|c|c|c|c|c|c|}
\hline 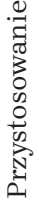 & 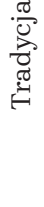 & 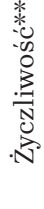 & 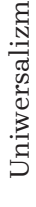 & 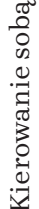 & $\frac{\frac{\pi}{0}}{\frac{\pi}{\sigma}}$ & 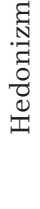 & 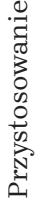 & 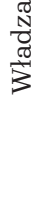 & 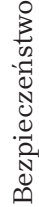 \\
\hline
\end{tabular}

$\mathrm{p}<.05,{ }^{*} \mathrm{p}<.02,{ }^{* *} \mathrm{p}<.01,{ }^{* * * *} \mathrm{p}<.001$

Źródło: opracowanie własne.

Przedstawione w tabeli 1 dane będące efektem badań własnych oraz ich rozkład graficzny na wykresie 1 pozwalają stwierdzić, że największe różnice, jeżeli chodzi o preferowane wartości wystąpiły pomiędzy grupami studentów i uczniów w zakresie następujących wartości: życzliwość, stymulacja, bezpieczeństwo i hedonizm. Są to różnice o znaku dodatnim, a więc pokazujące w tym przypadku, że to badani uczniowie częściej preferowali wymienione wartości. Przy tym różnica w zakresie życzliwości okazała się istotna statystycznie $(\mathrm{p}<0,02)$, a pozostałe nie są istotne statystycznie, chociaż są to zależności znaczące. Jeżeli chodzi o różnicę w preferowanych wartościach to okazało się również, że w przypadku takiej wartości jak uniwersalizm wystąpiła wyraźna różnica między badanymi studentami i uczniami, której znak jest ujemny. Różnica ta wskazuje, że to badani studenci (grupa S) częściej preferowali tę wartość niż respondenci z grupy U.

Poczucie jakości życia młodzieży studiującej i uczącej się

Zastosowane narzędzie (tzn. Skala Satysfakcji z Życia - SWLS) autorstwa E. Dienera i współpracowników w polskiej adaptacji 
Z. Juczyńskiego ${ }^{31}$ jako miara poczucia jakości życia badanej młodzieży studiującej i uczącej się daje Skala Satysfakcji z Życia i jej wynik ogólny w postaci sumy punktów. W związku z tym dla przejrzystości prezentowanych wyników badań obu grup młodzieży zostaną one przedstawione razem w jednej tabeli i na jednym wykresie (por. tabela 2 i wykres 2).

Tabela 2. Poziomy ogólnych wskaźników satysfakcji z życia (OWSż) w grupie uczniów i studentów oraz różnica między nimi

\begin{tabular}{|c|c|c|c|c|}
\hline $\begin{array}{c}\text { Uczniowie } \\
\mathbf{n}=\mathbf{1 0 0}\end{array}$ & $\begin{array}{c}\text { Studenci } \\
\mathbf{n}=\mathbf{1 0 0}\end{array}$ & $\begin{array}{c}\text { Różnica } \\
\text { średnich }\end{array}$ & $\begin{array}{c}\text { test } \\
(\mathbf{d f}=\mathbf{1 9 8})\end{array}$ & $\mathbf{p}$ \\
\hline 19 & 20,64 & $1,64^{*}$ & 2,22 & 0,05 \\
\hline
\end{tabular}

$\mathrm{p}<.05,{ }^{*} \mathrm{p}<.02,{ }^{* *} \mathrm{p}<.01, * * * \mathrm{p}<.001$

Źródło: opracowanie własne.

Wykres 2. Rozkład graficzny poziomów ogólnych wskaźników satysfakcji z życia $($ OWSŻ) w grupie uczniów i studentów

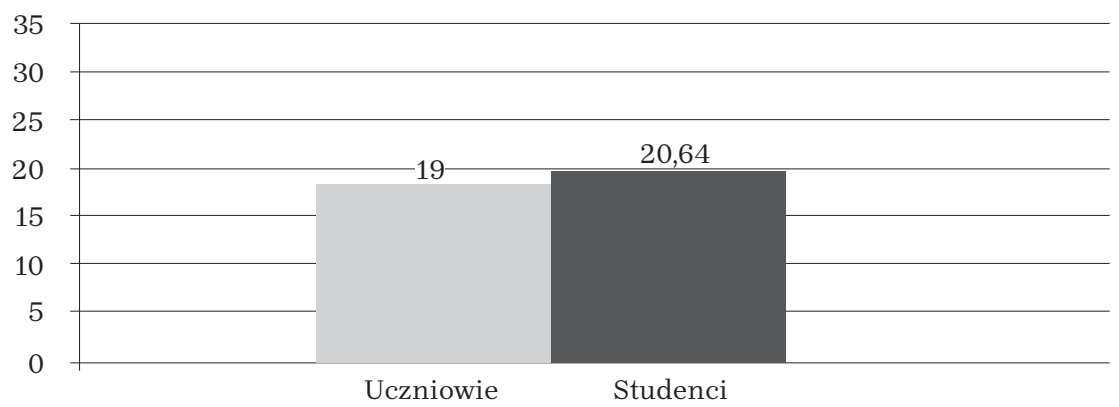

Źródło: opracowanie własne.

Dane umieszczone w tabeli 2 i na wykresie 2 pozwalają stwierdzić, że obie grupy badanej młodzieży różnią się na poziomie istotnym $(\mathrm{p}<$ 0,05), jeżeli chodzi o poziom ogólnego wskaźnika satysfakcji z życia ${ }^{32}$. W tym przypadku okazało się, że wyższy poziom satysfakcji z życia charakteryzuje grupę badanych studentów. Na podkreślenie zasługuje też fakt, że w grupie badanych uczniów znalazło się więcej osób, które

31 Z. Juczyński, Narzędzia pomiaru..., s. 134-138.

32 Ten wskaźnik przyjęto jako miarę poczucia jakości życia badanej młodzieży studiującej i uczącej się. 
osiągnęły wyniki wysokie poczucia jakości życia (17\% respondentów osiągnęło wynik OWSŻ $\geq 8$ stenów) niż w grupie badanych studentów (10\% respondentów).

\section{Preferowane wartości przez badaną młodzież studiującą i uczącą się a poczucie jakości życia}

Celem udzielenia odpowiedzi na sformułowany problem badawczy dokonano podziału otrzymanych wyników badań własnych w ramach każdej z grup młodzieży (tzn. tak studiującej jak i uczącej się) charakteryzujących poziomy poczucia jakości życia badanych studentów i uczniów na dwie podgrupy.

- Podgrupa 1 - badani studenci (tabela i wykres 3) lub uczniowie (tabela i wykres 4) o wyższym poziomie ogólnego wskaźnika satysfakcji z życia (OWSŻ > 5 stenów).

- Podgrupa 2 - badani studenci (tabela i wykres 3) lub uczniowie (tabela i wykres 4) o niższym poziomie ogólnego wskaźnika satysfakcji z życia (OWSŻ $\leq 5$ stenów).

Dla tak utworzonych podgrup badanych studentów i uczniów obliczono powtórnie wartości średnich arytmetycznych charakteryzujących preferowane przez nich wartości. Otrzymane w ten sposób dane umieszczono w tabelach 3 i 4, a ich rozkłady graficzne przedstawiono na wykresach 3 i 4.

Przedstawione w tabeli 3 i na wykresie 3 dane pozwalają stwierdzić, że zdecydowanie najwyższe różnice (istotne statystycznie $-\mathrm{p}<0,001$ ) wystąpiły między studentami o wyższym i niższym ogólnym wskaźniku satysfakcji z życia w zakresie wartości - przystosowanie. W tym przypadku okazało się, że osoby oceniające niżej swoją satysfakcję z życia zdecydowanie częściej preferują wyżej wymienioną wartość. Wydaje się, że na uwagę zasługują również różnice, jakie wystąpiły między obu podgrupami studentów w zakresie preferencji takich wartości jak: hedonizm i władza. Odnośnie do hedonizmu to jest on bardziej preferowany przez studentów o wyższym ogólnym wskaźniku satysfakcji z życia (OWSŻ > 5). Z kolei władza jest częściej preferowaną wartością w podgrupie studentów o OWSŻ $\leq 5$. 
Tabela 3. Preferencje wartości w grupach studentów o wyższym i niższym ogólnym wskaźniku satysfakcji z życia (OWSż) oraz różnice między nimi

\begin{tabular}{|l|c|c|c|c|c|}
\hline \multicolumn{1}{|c|}{ Wartości } & $\begin{array}{c}\text { Studenci } \\
\text { OWSŻ }>\mathbf{5} \\
(\mathbf{n}=\mathbf{4 9})\end{array}$ & $\begin{array}{c}\text { Studenci } \\
\text { OWSŻ } \leq \mathbf{5} \\
(\mathbf{n}=\mathbf{5 1})\end{array}$ & $\begin{array}{c}\text { Różnica } \\
\text { średnich }\end{array}$ & $\begin{array}{c}\text { test } \\
(\mathbf{d f}=\mathbf{1 9 8})\end{array}$ & $\mathbf{p}$ \\
\hline Przystosowanie & $\mathbf{0 , 1 3}$ & $\mathbf{1 , 1 2}$ & $\mathbf{- 0 , 9 9 * * *}$ & $-\mathbf{3 , 3 6}$ & $\mathbf{0 , 0 0 1}$ \\
\hline Tradycja & $-0,36$ & $-0,27$ & $-0,09$ & $-0,14$ & ni. \\
\hline Życzliwość & $-0,03$ & $-0,02$ & $-0,01$ & $-0,13$ & ni. \\
\hline Uniwersalizm & 0,45 & 0,49 & $-0,04$ & $-0,23$ & ni. \\
\hline Kierowanie sobą & 0,37 & 0,26 & 0,11 & 0,58 & ni. \\
\hline Stymulacja & $-0,2$ & $-0,31$ & 0,11 & 0,55 & ni \\
\hline Hedonizm & $-0,23$ & $-0,52$ & 0,25 & 1,26 & ni. \\
\hline Osiągnięcia & $-0,1$ & $-0,02$ & 0,01 & 0,11 & ni. \\
\hline Władza & $-1,16$ & $-0,92$ & $-0,24$ & $-0,73$ & ni. \\
\hline Bezpieczeństwo & 0,34 & 0,34 & 0,00 & 0,00 & ni. \\
\hline
\end{tabular}

$\mathrm{P}<.05,{ }^{*} \mathrm{p}<.02,{ }^{* * *} \mathrm{p}<.01, * * * \mathrm{p}<.001$

Źródło: opracowanie własne.

Wykres 3. Rozkład graficzny różnic w preferencjach wartości między grupami studentów o wyższym i niższym OWSż

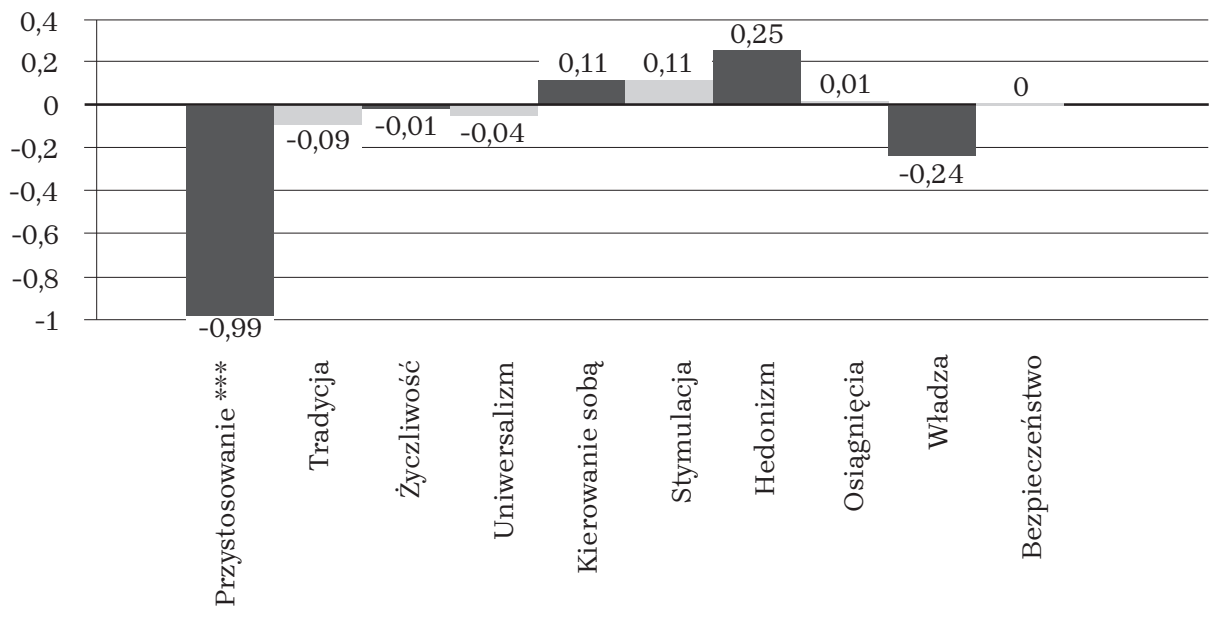

Źródło: opracowanie własne. 
Tabela 4. Preferencje wartości w grupach uczniów o wyższym i niższym ogólnym wskaźniku satysfakcji z życia (OWSż) oraz różnice między nimi

\begin{tabular}{|l|c|c|c|c|}
\hline \multicolumn{1}{|c|}{ Wartości } & $\begin{array}{c}\text { Uczniowie } \\
\text { OWSŻ } \leq \mathbf{5} \\
(\mathbf{n}=\mathbf{5 6})\end{array}$ & $\begin{array}{c}\text { Różnica } \\
\text { średnich }\end{array}$ & $\begin{array}{c}\text { test } \\
(\mathbf{d f}=\mathbf{1 9 8})\end{array}$ & $\mathbf{p}$ \\
\hline Przystosowanie & $-0,14$ & 0,05 & 0,78 & ni. \\
\hline Tradycja & $-0,57$ & 0,22 & 1,32 & ni. \\
\hline Życzliwość & $\mathbf{0 , 4 6}$ & $\mathbf{- 0 , 8 8 * *}$ & $\mathbf{- 2 , 8 0}$ & $\mathbf{0 , 0 1}$ \\
\hline Uniwersalizm & 0,24 & $-0,06$ & $-0,35$ & ni. \\
\hline Kierowanie sobą & 0,38 & $-0,02$ & $-0,65$ & ni. \\
\hline Stymulacja & 0,085 & $-0,185$ & $-0,57$ & ni \\
\hline Hedonizm & $-0,09$ & 0,01 & $-0,56$ & ni. \\
\hline Osiągnięcia & $-0,07$ & 0,15 & 0,67 & ni. \\
\hline Władza & $-0,93$ & 0,09 & 0,80 & ni. \\
\hline Bezpieczeństwo & 0,085 & $-0,185$ & $-0,57$ & ni. \\
\hline
\end{tabular}

$\mathrm{p}<.05,{ }^{*} \mathrm{p}<.02,{ }^{* * *} \mathrm{p}<.01,{ }^{* * *} \mathrm{p}<.001$

Źródło: opracowanie własne.

Wykres 4. Rozkład graficzny różnic w preferencjach wartości między grupami uczniów o wyższym i niższym OWSż

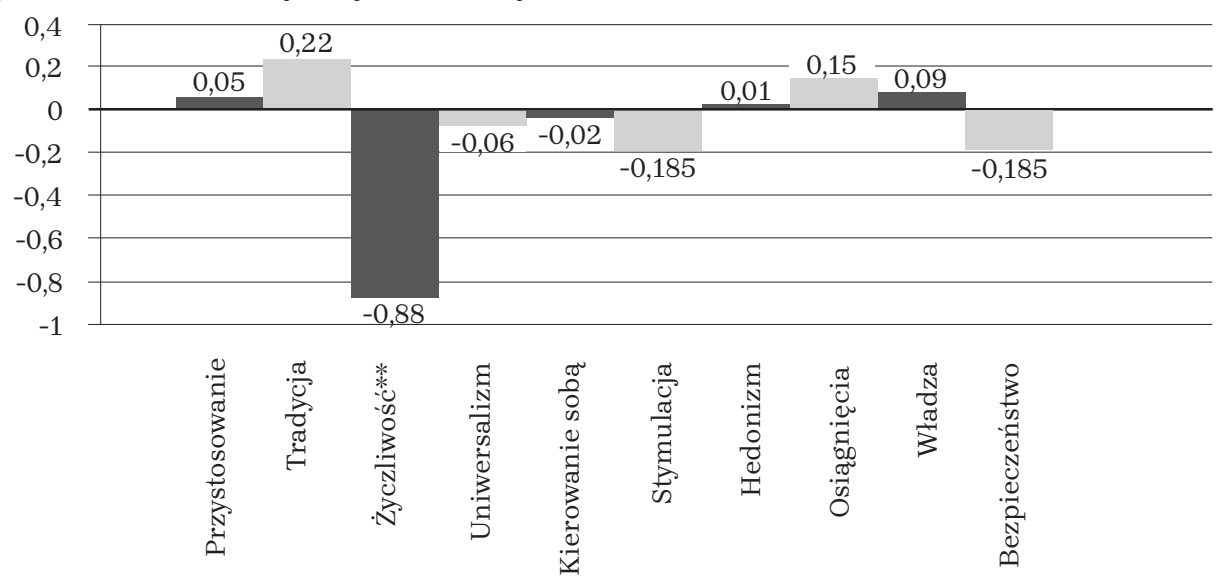

Źródło: opracowanie własne. 
Umieszczone w tabeli 4 i na wykresie 4 dane wskazuja, że zdecydowanie najwyższe różnice (istotne statystycznie $-\mathrm{p}<0,02$ ) wystąpiły pomiędzy studentami o wyższym i niższym ogólnym wskaźniku satysfakcji z życia w zakresie wartości- życzliwość. W tym przypadku okazało się, że osoby oceniające niżej swoją satysfakcję z życia zdecydowanie częściej preferują tę wartość. Na uwagę zasługuje również różnica jaka wystąpiła między obu podgrupami uczniów w zakresie takiej wartości jak tradycja. Wartość ta jest przy tym częściej perforowana w podgrupie uczniów o OWPŻ $>5$.

Tabela 5. Wartości według rangi przypisanej im na podstawie średniej wyboru w grupach studentów o wyższym i niższym ogólnym wskaźniku satysfakcji z życia (OWSż)

\begin{tabular}{|c|c|c|c|c|c|}
\hline Wartości & $\begin{array}{c}\text { Studenci } \\
\text { OWSŻ }>5 \\
(n=49)\end{array}$ & 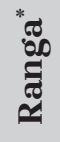 & Wartości & $\begin{array}{c}\text { Studenci } \\
\text { OWSŻ } \leq \mathbf{5} \\
(\mathbf{n}=\mathbf{5 1})\end{array}$ & 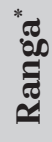 \\
\hline Uniwersalizm & 0,45 & $\mathbf{1}^{+}$ & Przystosowanie & 1,12 & $\mathbf{1}^{+}$ \\
\hline Kierowanie sobą & 0,37 & $2^{+}$ & Uniwersalizm & 0,49 & $2^{+}$ \\
\hline Bezpieczeństwo & 0,34 & $3^{+}$ & Bezpieczeństwo & 0,34 & $3^{+}$ \\
\hline Przystosowanie & 0,13 & $\mathbf{4}^{+}$ & Kierowanie sobą & 0,26 & $\mathbf{4}^{+}$ \\
\hline Władza & $-1,16$ & $\mathbf{1}^{-}$ & Władza & $-0,92$ & $\mathbf{1}^{-}$ \\
\hline Tradycja & $-0,36$ & 2 & Hedonizm & $-0,52$ & 2 \\
\hline Hedonizm & $-0,23$ & $3^{-}$ & Stymulacja & $-0,31$ & $3^{-}$ \\
\hline Stymulacja & $-0,2$ & $4^{-}$ & Tradycja & $-0,27$ & $4^{-}$ \\
\hline Osiągnięcia & $-0,1$ & 5 & Życzliwość & $-0,02$ & 5 \\
\hline Życzliwość & $-0,03$ & $6^{-}$ & Osiągnięcia & $-0,02$ & 5 \\
\hline
\end{tabular}

* Rangi oznaczają dwa rodzaje preferencji (ze znakiem + to preferencja wyższa niż średnia preferencja wartości danej osoby; a ze znakiem oznaczają preferencje poniżej średniej preferencji danej osoby.

Źródło: opracowanie własne.

Przedstawione w tabeli 5 dane wskazują, że badani studenci o wyższym i niższym ogólnym wskaźniku satysfakcji z życia różnią się, jeżeli chodzi o preferowane wartości. Studenci o wyższym ogólnym wskaźniku satysfakcji z życia (OWSŻ > 5) najczęściej preferują takie wartości, jak: kierowanie sobą, uniwersalizm oraz bezpieczeństwo i przystosowanie. Studenci o niższym ogólnym wskaźniku satysfakcji z życia 
$($ OWSŻ $\leq 5)$ preferują z kolei takie wartości, jak: przystosowanie, uniwersalizm, bezpieczeństwo i kierowanie sobą. Biorąc pod uwagę preferencje studentów o wyższym ogólnym wskaźniku satysfakcji z życia są to wartości, które posługując się modelem kołowym Schwartza, można scharakteryzować odwołując się także do wymiarów:

1) przekraczanie siebie versus umacnianie siebie oraz otwartość na zmiany versus zachowawczość;

2) koncentracja na sobie versus koncentracja na innych oraz ochrona siebie versus wzrost.

Uwzględniając powyższe wymiary można stwierdzić, że wymienione wartości w przypadku pierwszego z wymiarów należą do otwartości na zmiany (kierowanie sobą), przekraczania siebie (uniwersalizm) oraz zachowawczości (bezpieczeństwo i przystosowanie). Z kolei odnosząc się do wymiaru drugiego można stwierdzić, że wybrane w tej grupie studentów wartości znalazły się najczęściej w tych elementach modelu kołowego Schwartza, które są motywowane ochroną siebie oraz koncentracją na innych (bezpieczeństwo i przystosowanie). Rzadziej z kolei wybierane w tej grupie respondentów wartości są motywowane wzrostem i koncentracją na innych (uniwersalizm) oraz wzrostem i koncentracją na sobie (kierowanie sobą).

Z kolei biorąc pod uwagę preferencje studentów o niższym ogólnym wskaźniku satysfakcji z życia (tabela 5) to są to wartości, które posługując się wymienionym modelem kołowym Schwartza, możemy scharakteryzować w następujący sposób. Uwzględniając powyższe wymiary można stwierdzić, że wymienione wartości w przypadku pierwszego z wymiarów należą do zachowawczości (bezpieczeństwo i przystosowanie) i otwartości na zmiany (kierowanie sobą) oraz przekraczania siebie (uniwersalizm). Z kolei odnosząc się do wymiaru drugiego można stwierdzić, że wybrane w tej grupie uczniów wartości są motywowane ochroną siebie oraz koncentracją na innych (bezpieczeństwo i przystosowanie). Rzadziej z kolei wybierane w tej grupie respondentów wartości są motywowane wzrostem i koncentracją na innych (uniwersalizm) oraz wzrostem i koncentracją na sobie (kierowanie sobą).

Umieszczone $\mathrm{w}$ tabeli 6 dane pozwalają stwierdzić, że badani uczniowie o wyższym i niższym ogólnym wskaźniku satysfakcji z życia różnią się jeżeli chodzi o preferowane wartości. Uczniowie o wyższym ogólnym wskaźniku satysfakcji z życia (OWSŻ > 5) najczęściej preferują takie wartości jak: kierowanie sobą, uniwersalizm oraz osiągnięcia. Są 
to wartości, które posługując się modelem kołowym Schwartza, możemy scharakteryzować jeżeli chodzi o pierwszy z wymiarów jako należące do otwartości na zmiany (kierowanie sobą), przekraczanie siebie (uniwersalizm) oraz umacnianie siebie (osiągnięcia). Z kolei odnosząc się do wymiaru drugiego można stwierdzić, że wybrane w tej grupie uczniów wartości są motywowane wzrostem i koncentracją na sobie (kierowanie sobą) oraz wzrostem i koncentracją na innych (uniwersalizm) lub ochroną siebie i koncentracją na sobie (osiągnięcia).

Tabela 6. Wartości według rangi przypisanej im na podstawie średniej wyboru w grupach uczniów o wyższym i niższym ogólnym wskaźniku satysfakcji z życia (OWSŻ)

\begin{tabular}{|c|c|c|c|c|c|}
\hline Wartości & $\begin{array}{c}\text { Uczniowie } \\
\text { OWSŻ > 5 } \\
(\mathbf{n}=44)\end{array}$ & 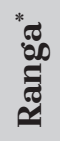 & Wartości & $\begin{array}{c}\text { Uczniowie } \\
\text { OWSŻ } \leq \mathbf{5} \\
(\mathbf{n}=\mathbf{5 6})\end{array}$ & $\begin{array}{l}* \pi \\
\approx 0 \\
\approx \\
\approx \\
\approx\end{array}$ \\
\hline Kierowanie sobą & 0,36 & $\mathbf{1}^{+}$ & Życzliwość & 0,46 & $\mathbf{1}^{+}$ \\
\hline Uniwersalizm & 0,18 & $\mathbf{2}^{+}$ & Kierowanie sobą & 0,38 & $2^{+}$ \\
\hline Osiągnięcia & 0,08 & $3^{+}$ & Uniwersalizm & 0,24 & $3^{+}$ \\
\hline Władza & $-0,84$ & $\mathbf{1}^{-}$ & Stymulacja & 0,085 & $\mathbf{4}^{+}$ \\
\hline Życzliwość & $-0,42$ & $2^{-}$ & Bezpieczeństwo & 0,085 & $\mathbf{4}^{+}$ \\
\hline Tradycja & $-0,35$ & $3^{-}$ & Władza & $-0,93$ & $\mathbf{1}^{-}$ \\
\hline Stymulacja & $-0,1$ & $4^{-}$ & Tradycja & $-0,57$ & $2^{-}$ \\
\hline Bezpieczeństwo & $-0,1$ & $4^{-}$ & Przystosowanie & $-0,14$ & $3^{-}$ \\
\hline Przystosowanie & $-0,09$ & $5^{-}$ & Hedonizm & $-0,09$ & $4^{-}$ \\
\hline Hedonizm & $-0,08$ & $6^{-}$ & Osiągnięcia & $-0,07$ & 5 \\
\hline
\end{tabular}

* Rangi oznaczają dwa rodzaje preferencji (ze znakiem + to preferencja wyższa niż średnia preferencja wartości danej osoby; a ze znakiem - oznaczają preferencje poniżej średniej preferencji danej osoby.

Źródło: opracowanie własne.

Z kolei biorąc pod uwagę preferencje uczniów o niższym ogólnym wskaźniku satysfakcji z życia (tabela 6) to są to wartości, które posługując się modelem kołowym Schwartza, możemy scharakteryzować w następujący sposób. Uwzględniając te wymiary można stwierdzić, że preferowane przez tę grupę respondentów (grupa U) wartości $\mathrm{w}$ przypadku pierwszego z wymiarów należą do przekraczanie siebie 
(życzliwość i uniwersalizm) i otwartości na zmiany (kierowanie sobą i stymulacja) oraz zachowawczość (bezpieczeństwo). Odnosząc się do wymiaru drugiego w modelu kołowym Schwartza można stwierdzić, że wybrane w tej grupie uczniów wartości są motywowane wzrostem i koncentracją na sobie (kierowanie sobą) lub wzrostem i koncentracją na innych (uniwersalizm) oraz ochroną siebie i koncentracją na sobie (osiągnięcia).

\section{Dyskusja wyników i zasadnicze wnioski}

Na podstawie analizowanych wyników badań można sformułować kilka ogólnych wniosków końcowych.

Po pierwsze, charakteryzowani studenci (grupa S) i uczniowie (grupa U) różnią się pod względem preferowanych wartości. Respondenci z grupy S najbardziej preferują takie wartości jak: uniwersalizm $(\mathbf{0 , 4 9 6})^{33}$, kierowanie sobą $(0,311)$ i przystosowanie $(0,181)$. Natomiast do najmniej preferowanych wartości należą: władza $(-1,043)$, hedonizm $(-0,379)$ i tradycja (-0,314). Z kolei dla respondentów z grupy U do najważniejszych wartości należą życzliwośćc $(\mathbf{0 , 4 4 5})$, kierowanie sobą $(\mathbf{0 , 3 7 5})$ i uniwersalizm $(\mathbf{0 , 2 1 7})$. Najmniejsze znaczenia mają dla tej grupy osób: władza $(-0,883)$ i tradycja $(-0,47)$. Można również stwierdzić, że w obu badanych grupach młodzieży (grupa S i U) preferowane wartości należą do kategorii nazwanej - przekraczanie siebie oraz są motywowane koncentracją na innych i wzrostem. W odniesieniu do najmniej preferowanych wartości znalazły się one w grupie nazwanej - umacnianie siebie oraz są motywowane koncentracją na sobie i ochroną siebie.

Po drugie, obie badane grupy młodzieży (tzn. grupa S i grupa U) różnią się między sobą na poziomie istotnym statystycznie $(p<0,05)$ w zakresie poziomu ogólnego wskaźnika satysfakcji z życia. Przy tym w grupie badanych uczniów znalazło się więcej osób, które wyżej oceniły swoje poczucie jakości życia (17\% respondentów osiągnęło wynik OWSŻ $\geq 8$ stenów) niż w grupie badanych studentów (10\% respondentów osiągnęło wyniki wysokie na skali stenowej).

33 Ipsatywny wskaźnik preferencji wartości to wskaźnik, który jest wynikiem różnicy pomiędzy średnią uzyskaną dla wszystkich wartości i średnią uzyskaną dla danego typu wartości. 
Po trzecie, w grupie studentów o wyższym i niższym poziomie ogólnego wskaźnika satysfakcji z życia wystąpiły istotne statystycznie różnice w zakresie preferencji takiej wartości jak przystosowanie. $Z$ kolei badani uczniowie o wyższym i niższym poziomie ogólnego wskaźnika satysfakcji z życia różnią się preferencją w zakresie wartości - życzliwość (różnica istotna statystycznie).

Po czwarte, dokonując szczegółowej analizy rozkładu preferowanych wartości w badanych grupach młodzieży studiującej (grupa S) i uczącej się (grupa U) z uwzględnieniem wymiarów, jakie opisują model kołowy S. Schwartza, można jeszcze wyraźniej zauważyć różnice między badanymi studentami i uczniami o wyższym i niższym ogólnym wskaźniku satysfakcji z życia. W tym kontekście to większe różnice wystąpiły w grupie uczniów o wyższym i niższym ogólnym wskaźniku satysfakcji z życia. Szczególnie w przypadku wymiaru motywującego wybór określonych wartości okazało się, że w grupie badanych uczniów o niższym ogólnym wskaźniku satysfakcji z życia wystąpiło więcej preferowanych wartości. Są to wartości dwa razy częściej motywowane przez wzrost oraz koncentrację na innych lub na sobie.

Po piąte, obie badane grupy młodzieży (tzn. grupa studentów i uczniów) są w okresie jeszcze wciąż dokonującego się dynamicznie rozwoju systemu wartości. Dlatego też tak w badanej grupie studentów jak i uczniów mamy do czynienia z częstym preferowaniem przez osoby z obu grup wartości, które zgodnie z modelem kołowym Schwartza są sprzeczne ze sobą, jeżeli chodzi o ich usytuowanie w tym modelu ${ }^{34}$. W grupie studentów były wyraźnie preferowane takie wartości jak bezpieczeństwo (wymiar zachowawczość), a z drugiej strony taka wartość jak kierowanie sobą (otwartość na zmiany), czy też z kolei taka wartość jak przystosowanie (wymiar zachowawczość) oraz kierowanie sobą (otwartość na zmiany). W przypadku badanych uczniów również mamy do czynienia z preferowaniem sprzecznych ze sobą wartości. Dla przykładu są to kolejno np. taka wartość jak uniwersalizm (wymiar przekraczania siebie) oraz taka wartość jak osiągnięcia (wymiar umacniania siebie), czy z kolei taka wartość jak kierowanie sobą (otwartość na zmiany) oraz taka wartość jak bezpieczeństwo (zachowawczość).

34 Zasada konfliktu przeciwległych wartości, por. J. Cieciuch, Kształtowanie się systemu..., s. 46. 


\begin{abstract}
The author of the article presents a description and interpretation of the results of original research carried out in groups of young people studying at university and secondary schools. The research concerned the values of these groups of young people and their perceived quality of life. In his research, the author uses the Shalom Schwartz's Portrait Values Questionnaire (PVQ) in the Polish adaptation of J. Cieciuch and Z. Zaleski and the Life Satisfaction Scale by Diener et al. in the Polish adaptation of Juczyński. The results of the research are presented in the article and conclusions are formulated on this basis, which can be an interesting source of data for people who currently organize and implement the broadly understood educational processes in universities and high schools.
\end{abstract}

\title{
Bibliografia
}

Owsiński W., Tarchalski T., Pomiar jakości życia. Uwagi na marginesie pewnego rankingu, „Współczesne Problemy Zarządzania” 2008, nr 1.

Borys T., Jakość, jakość życia oraz pojęcia i relacje pochodne, [w:] W. Ostasiewicz, (red.), Ocena i analiza jakości życia, Wydawnictwo Akademii Ekonomicznej we Wrocławiu, Wrocław 2004.

Campbell A., Subjective Measures of Well-being, „American Psychologist" 1976, t. 31, nr 2.

Cieciuch J., Kształtowanie się systemu wartości od dzieciństwa do dorosłości, Wydawnictwo Liberi Libri, Warszawa 2013.

Cieciuch J., Zaleski Z., Polska adaptacja Portretowego Kwestionariusza Wartości Shaloma Schwartza, „Czasopismo Psychologiczne” 2011, t. 17 , nr 2.

Daszykowska J., Jakość źycia w perspektywie pedagogicznej, Oficyna Wydawnicza „Impuls”, Kraków 2007.

Derbis R., Doświadczanie codzienności: poczucie jakości życia, swoboda działania, odpowiedzialność, wartości osób bezrobotnych, Wydawnictwo WSiP, Częstochowa 2000.

Dziewiecki M., Wychowanie ku wartościom (1), „Wychowawca” 1998, nr 9.

Grzegorczyk A., Życie jako wyzwanie, Wydawnictwo IFIS, Warszawa 1993.

Juczyński Z., Narzędzia pomiaru w promocji i psychologii zdrowia. Skala Satysfakcji z Życia, Pracownia Testów Psychologicznych Polskiego Towarzystwa Psychologicznego, Warszawa 2001.

Misztal M., Problematyka wartości w socjologii, PWN, Warszawa 1980.

Oleś P., Wartościowanie a osobowość. Psychologiczne badania empiryczne, Redakcja Wydawnictw KUL, Lublin 1989. 
Pavot W., Diener E., The affective and cognitive context of self-reported measures of subjective well-being, "Social Indicators Research” 1993, t. 28.

Popielski K., Sens i wartość życia jako kategorie antropologiczno-psychologiczne, [w:] K. Popielski (red.), Człowiek - pytanie otwarte, Redakcja Wydawnictw KUL, Lublin 1987.

Reykowski J., Teoria motywacji a zarzq̨dzanie, PWN, Warszawa 1975.

Rokeach M., The nature of human values, The Free Press, New York 1973.

Schwartz S.H., Basic human values: theory measurement and applications, „Revue francaise de sociologie” 2006, t. 47(4).

Schwartz S.H., Bilsky W., Toward a psychological structure of human values, „Journal of Personality and Social Psychology” 1987, t. 53.

Shin D.C., Johnson D.M., Avowed Happiness as the Overall Assesment of the Quality of Life, „Social Indicators Research” 1978, t. 5.

Straś-Romanowska M., Jakość życia w świetle założeń psychologii zorientowanej na osobę, „Kolokwia Psychologiczne” 2005, nr 13. 